\title{
Efforts to Improve Rice Milling Capacity in Tidal Swamp Agroecosystem in Banyuasin Regency, South Sumatra
}

\author{
Yanter Hutapea ${ }^{1, *}$, Tumarlan Thamrin ${ }^{1}$, and Budi Raharjo $^{1}$ \\ ${ }^{1}$ South Sumatera Assessment Institute for Agricultural Technology
}

\begin{abstract}
Compared to when the rice planted once in a year, now the increase of rice cropping index $(\mathrm{CI})$ does not have much impact on the increase of rice milling work capacity in tidal swamp agroecosystem. This study aims to identify the causes of rice milling work capacity decrease and provide suggestions to increase the working capacity of rice milling. The survey was conducted in 2019 in Muliasari Village, Tanjung Lago Sub District as an easily accessible location and Sumber Hidup Village in Muara Telang Sub District as a relatively difficult location to reach, both located in Banyuasin Regency, South Sumatera Province. Descriptive data analysis quantitatively and qualitatively was done as comparisons. The results of this study indicate that: There are insufficient time and labor to carry out grain drying due to the immediate replanting of paddy fields to increase CI. Reactivating rice milling gives an impact on the use of leftovers such as husks and bran so that the added value can be used in the village. Policy suggestions through this activity are 1) guaranteed more favorable selling prices for rice, 2) rice processing diversification, and 3) reactivating post-sale activities through the use of food barns.
\end{abstract}

\section{Introduction}

Rice as a staple food requires special attention in term of productivity and yield quality. Higher productivity and quality obviously have important implications for better supply and hence for food security [1]. Agricultural development especially on tidal swamp areas with rice as the main commodity is a strategic step taken by the government to secure food production, equitable distribution for development between regions, increase productivity and standard of living. The agricultural intensification program promoted by the government has increased the demand for agricultural tools and machinery rapidly. With the use of short-lived rice varieties development, attention has arisen in how to do harvest and post-harvest. Rapid development also occurred at the Rice Milling Unit (RMU). Smallscale milling machines are fast developing and easily accepted, due to several reasons such as low operating costs, easy to operate, the better quality of rice produced, higher yields, in addition to the bran can be utilized.

\footnotetext{
*Corresponding author: hutapeayanter@yahoo.co.id
} 
Rice milling is an important chain in the rice supply in terms of both quantity and quality to support food security. Therefore rice milling has an important role in the Indonesia rice agribusiness system. This role is reflected in the number and rice production distribution centers. The increasing of Rice Cropping Index (CI) is expected to provide broad opportunities to process yields by post-harvest institutions, but in fact, rice milling activities are declining.

The results of the study also showed that in 2016 there was a decline in rice mill production capacity. In general, the current working capacity of the RMU is only around $15 \%$ compared to before, when farmers planted once a year in the tidal area. Problems with low rice mills work capacity, apart from being caused by the farmers working time who are seized to immediately cultivate the land and replant it, also because of the limited postharvest facilities. Fresh harvest rice purchased directly by large rice entrepreneurs not only from South Sumatera Province but also outside provinces such as Lampung, Jambi, and Bengkulu. The non-milling of fresh harvest rice in the village causes the added value that can be obtained from the husk. The rice bran is not only enjoyed by farmers in the village but also the buyers from outside South Sumatera [2]. So, it is important to study how to make milling work capacity increases in rural areas, following the increase of dry harvested grain production due to the target increase in CI. The purpose of this study is to identify the causes of the decline of rice mill work capacity and to provide suggestions to increase the working capacity of the rice mills.

\section{Methodology}

The survey was conducted in 2019 in Muliasari Village, Tanjung Lago Sub District, and Sumber Hidup Village, Muara Telang Sub District, both in Banyuasin Regency of South Sumatera Province. Both villages were dominated by transmigrant residents in Tidal Swamp Agroecosystem. Muliasari Village is located in an area that is easy to reach by fourwheeled vehicles (truck), compared to Sumber Hidup Village as a location that is relatively difficult to reach because it has to go through the river.

Data were collected through interviews with 20 farmers and 5 rice mill managers in each village, relevant agency officials, and discussions at group meetings. Besides, reports from related institutional activities, research results, and previous studies and statistical data were also be used.

Data collected include rice milling conditions and operations, availability of labor for drying rice, and respondent's opinion on grain/rice sales. The data and information obtained were analyzed descriptively both in quantitative and qualitative. The comparative analysis is carried out to distinguish conditions before and after the policy runs or to distinguish conditions between two locations at the same time.

\section{Results and Discussion}

\subsection{General Conditions of Rice Milling}

Based on the physical structure of the rice mill, there is $80 \%$ of the mill uses tiles and $20 \%$ combination of zinc with asbestos in Muliasari Village. In Sumber Hidup Village $60 \%$ of rice mills use asbestos, $20 \%$ zinc, and $20 \%$ combination of zinc and tiles. In Muliasari Village, the rice milling floor is $40 \%$ dominant soil and $60 \%$ dominant rock/cement. The rice milling floor in Sumber Hidup Village is $20 \%$ dominant land soil and $80 \%$ dominant rock/cement. At the moment, the condition of the rice milling machine in Muliasari Village 
is $80 \%$ in good condition (rarely damaged) and $20 \%$ in moderate condition (the tool has been damaged slightly). In Sumber Hidup Village, 20\% of machines are in good condition and $80 \%$ are moderate. The average mill capacity in Muliasari Village is $540 \mathrm{~kg}$ rice/hour and in Sumber Hidup Village is 1,040 kg rice/hour. Research conducted by [3] mentioned that in the tidal swamp area, moisture content of both unhusked rice and milled rice varied from 14.6 to $15.0 \%$ and from 14.5 to $15.1 \%$, respectively.

The feasibility analysis of a small-scale rice milling business carried out in Tanjung Morawa Sub- District, Deli Serdang Regency, North Sumatera Province shows that the source of raw material for grain is obtained from farmers around the mill with an average of $85.4 \mathrm{t} /$ year of unhulled rice. The average net Benefit/Cost $(\mathrm{Net} \mathrm{B} / \mathrm{C})$ is 1.3 with the Internal Rate of Return (IRR) of $24.7 \%$. Thus this small-scale rice mill is worth to build [4].

There is a mobile rice mill in Muliasari Village now and it can be a competitor for conventional rice millers. It can decrease the working capacity or operational capacity of rice mills because it is easier for farm households to contact the mobile mills to mill their grain into rice for consumption. The mobile rice mill has also been used in several locations such as in West Sumbawa which produces medium quality rice class II [5]. In Pringsewu Regency, Lampung, with a 10:1 profit sharing between grain owners and mobile millers [6]. Meanwhile, the mobile rice milling in Tumale Village, Ponrang Sub District, Luwu Regency categorized feasible to be operated with an indicator of $\mathrm{Net} B / \mathrm{C}$ value of 1.2 and IRR of $46.29 \%$ [7].

A study conducted in Nigeria [8] showed that inadequate resources and poverty are obstacles to the adoption and development of modern technology in rice processing. Research conducted by [9], assert that the government is advised to help subsidize the cost of modern equipment to enable processors replace their spoiled parts to put back their equipment's to work.

\subsection{Rice Milling with Decreased Work Capacity}

Economically, the mill has the advantage of its activity. Currently, many rice mills have decreased their work capacity compared to 10 years ago, when farmers were still planting rice once a year, both in areas that are easily accessible by four-wheeled vehicles, or relatively difficult because they have to be traveled through the river. Starting in July / August some mills in the village reduced their activity. If it does not go through reducing the working hours, then the working day will reduce, or both. Rice milling activities begin to increase at the time of harvest in February / March. Admittedly, the planting pattern of planting rice only once a year in the village caused the factory enter a period of rest. After the rice harvest, 1,089 ha of paddy fields in Muliasari Village were planted with corn towards the end of May [2].

Table 1. Number of milling operation days and milled grain per year

\begin{tabular}{|l|l|r|r|r|}
\hline \multirow{2}{*}{ Location } & Description & $\begin{array}{c}\text { Before } \\
\mathbf{( 2 0 1 0 )}\end{array}$ & $\begin{array}{c}\text { After } \\
(\mathbf{2 0 1 8 - 2 0 1 9 )}\end{array}$ & Gap \\
\hline Muliasari & Operation days RMU (day) & 231 & 105 & 126 \\
\cline { 2 - 5 } Village & Milled grain (kg dry milled grain) & 3,138 & 915 & 2,223 \\
\hline \multirow{2}{*}{$\begin{array}{l}\text { Sumber Hidup } \\
\text { Village }\end{array}$} & Operation days RMU (day) & 190 & 108 & 82 \\
\cline { 2 - 5 } & Milled grain (kg dry milled grain) & 33,923 & 20,250 & 13,673 \\
\hline
\end{tabular}

Note: Before $(2010)=$ CI 100

After $(2018-2019)=\mathrm{CI} \geq 200$ 
The reduced mill working capacity as stated before, also caused by dry harvested grain that was directly bought by collectors from outside province such as Lampung and by rice traders whose factories are located in Pegayut Village, South Sumatera. It continues because rice harvest usually occurs during the rainy season, while the existing drying facilities are unable to serve grain drying simultaneously.

The operation days of rice milling currently reduced compared to 2010 . The total reduction in operating days is 126 days, with milled grain reduced by 2,223 $\mathrm{kg}$ in Muliasari Village. Whereas in Sumber Hidup Village, the number of operational days decreased by 82 days with milled grain reduced by $13,673 \mathrm{~kg}$ (Table 1 ).

The government program to increase the availability of national rice is implemented through an increase in Rice CI. The increase in CI decreases the working time of farmers to do unhulled rice especially if the drying process is carried out during the rainy season. Unavailability or lack of drying facilities increases the chances of selling grain without the drying process. Research conducted in Kenya [10] revealed that the existing capacity of rice mills is adequate to meet increased rice production, however a number of challenges need to improve the efficiency of production increase and competitiveness through exploiting opportunities in improving capacity and post-harvest technology.

A study conducted in Subang, West Java [11] assert that among three drying technologies, namely sun drying floor, flatbed dryer using husk fuel and flatbed dryer using gas fuel, flatbed dryer using rice husk fuel is the most profitable, feasible, and prospective for adoption. Therefore, this type of dryer must be promoted intensively to farmer group associations, rice traders, and rice millers.

Farmers's households were still dominated by only planting their paddy fields once with paddy in 2010. At present (2019), in Mulyasari Village 80\% of farmers apply the rice-corn cropping pattern and $20 \%$ with rice-corn-watermelon. Whereas in Sumber Hidup Village $65 \%$ of farmers apply the paddy-paddy cropping pattern and $35 \%$ with paddy- paddy-corn. As a location that is easily accessible and relatively closer to the provincial capital, Mulyasari Village has more diverse plants than relatively difficult to reach locations (Sumber Hidup Village) with a combination of fruits. The identification of cropping patterns in East Java [12] resulted several main cropping patterns based on paddy, such as: paddy-paddy- secondary crops, paddy-paddy- fallow, paddy-secondary crop-secondary crop, paddy- secondary crops-fallow. Planting more than once per year in paddy fields is also a way to reduce the impact of reduced food production due to the conversion of paddy fields.

Table 2. Farmer's household time available to dry the grain in the rainy and dry season

\begin{tabular}{|l|c|c|}
\hline Time available to dry the grain & $\begin{array}{c}\text { Muliasari } \\
\text { Village }\end{array}$ & $\begin{array}{c}\text { Sumber Hidup } \\
\text { Village }\end{array}$ \\
\hline Rainy Season & & \\
\hline Available (\% farmer) & 15 & 4 \\
\hline Quite available (\% farmer) & 20 & 35 \\
\hline Unavailable (\% farmer) & 65 & 60 \\
\hline Dry Season & & \\
\hline Available (\% farmer) & 65 & 25 \\
\hline Quite available (\% farmer) & 35 & 75 \\
\hline Unavailable (\% farmer) & - & - \\
\hline
\end{tabular}

The increase in CI, both from CI 200 to 300 and CI 100 to 200 affects the available time of farm households to dry the grain. In Muliasari Village and Sumber Hidup Village, 65\% and $60 \%$ of farmers stated that there was no time to dry the grain in the rainy season (Table 2). Whereas in the dry season in Muliasari Villages and Sumber Hidup Villages as much as 
$35 \%$ and $75 \%$ of farmers stated that there was enough time to dry the grain.

The current harvest has using a combine harvester, which costs are cheaper because it saves IDR 1,000,000 / ha compared to use a harvesting group. To reduce the risk of yield damage, farmers sell it in the form of dry harvested grain. Clearly, it causes rice husks and bran cannot be used in the village area [2].

Among post-harvest operations, drying is the main process to improve rice yield. The importance of reducing the moisture content of cereal plants is to prevent the growth of microorganisms [13]. In Sumber Hidup Village 55\% of the farmers did sun-drying, 20\% use artificial dryer and the remaining $24 \%$ did both to dry the grain. Meanwhile, all farmers did sun-drying in Muliasari Village. This is also related to the number of dryers in the rice mill, where all mills surveyed in Sumber Hidup Village have grain dryers. For example, one of grain dryer (oven) is using wood as fuel. The drying capacity of $7 \mathrm{t}$ dry harvested grain uses 20 hours of working time (16-17 hours of oven operation and the remaining 3-4 hours is the time for putting the grain, cooling process, and removing grain from the oven). The relative difficulty of reaching Sumber Hidup Village has encouraged the use of grain dryers. Conversely, easy access to Muliasari Village causes farmers only dry the grain with sunshine, even sell wet grain.

Paddy drying has significant effect to the rice quality, since any delay in drying and also uneven drying will result in qualitative and quantitative of losses [14]. Many farmers lose much profit due to poor drying process. Therefore, application of a suitable drying technology is very important [15]. Moreover, research conducted by [16] revealed if an artificial dryer is not available, rough rice should be sun dried only in the morning to avoid afternoon heat with frequent stirring and mixing to promote more even drying. The comparative analysis conducted by [17] among the different drying in Vietnam, Cambodia, Philippines and Myanmar give the recommendation for the most appropriate options based on indicators of greenhouse gas emissions, energy efficiency, drying cost, and market demands. These factors also determine a proper drying to use.

The business of making husk charcoal in the two villages already exists, but it has not well developed because the use is still limited, such as being returned to the land or need to mix with planting media. Though the use of husk charcoal can also be used for charcoal briquettes and others. To develop the use of dryers with fuel husks, there are workshops in rural areas that can be used to overcome the damage or to modify equipment as has been done so far.

There are several reasons why farmers sell fresh harvest rice instead of milled rice. These reasons are rational, especially in the short term to get money. More profitable selling grain is the clearest reason, meanwhile the lack of manpower to dry rice is related to the lack of time for replanting immediately to increase CI. These reasons all occur both in easily accessible areas (Muliasari Village), and those that are relatively difficult (Sumber Hidup Village).

Table 3. Farmer's reasons to sell fresh harvest rice instead of milled rice

\begin{tabular}{|l|c|c|}
\hline Reasons & $\begin{array}{c}\text { Muliasari } \\
\text { Village }\end{array}$ & $\begin{array}{c}\text { Sumber Hidup } \\
\text { Village }\end{array}$ \\
\hline More profitable (\% farmer) & 80 & 75 \\
\hline Lack of labor to dry (\% farmer) & 60 & 20 \\
\hline Lack of drying facilities (\% farmer) & 45 & 30 \\
\hline
\end{tabular}

Note: respondent can choose more than one answer

There is no difference between the two types of locations because in locations that are difficult to reach, that must go through the river, the motorboat takes the harvested grain to a large factory which is located on the edge of the river, or grain was unloaded at the river 
pier where trucks were waiting to bring it to large factories in Southern Sumatra and even outside the province such as Lampung.

Based on the above problem, the decreasing of rice milling capacity is caused by:

\subsubsection{Limited labor for drying fresh harvest rice}

The limited labor available for drying fresh harvest rice is because of the need to catch rice planting time following the government program to increase the CI. Hence the grain drying business (dryer) that existed needs to be revived to overcome the limitations of drying labor. This work will create employment for farming communities in rural areas as dryer operators.

\subsubsection{Farmers are more interested in selling fresh harvest rice than milled rice}

Farmers do not do processing or drying activities that require additional costs, although "it is possible" to obtain additional income. The amount does not affect farmers to do rice milling, because to obtain an additional amount or greater than the added value due to changes in the form of fresh harvest rice into milled rice, farmers can get it from other activities. However, farmers face the risk of damage/losses of yield. So the rice selling price must attract farmers to do rice milling. Additional costs in processing fresh harvest rice into milled rice such as the transportation cost from the rice fields to the house, drying cost, transportation cost from the house to the factory, milling, and packing cost. By directly selling fresh harvest rice, farmers feel helped because grain marketing is running smoothly. Large traders and agents are ready in the fields to transport the fresh harvest rice.

The core of the problem is the rice selling price at the field level must increase so that farmers want to change their fresh harvest rice into the milled rice. Indeed, in rice farming, farmers are also not spared from production, price and income risks [18]. An example is given by Mr. Agus Susanto, one of the owners of a rice mill in Sumber Hidup Village. The plant has fresh harvest rice that needs to be dried and ground into the rice. In May 2019 the price of fresh harvest rice was IDR $4,300-4,500 / \mathrm{kg}$, with the price of milled rice sold at the place (factory) only IDR $7,700 / \mathrm{kg}$ or IDR $7,800 / \mathrm{kg}$. Of course, the price of milled rice is not feasible because of the shrinkage from fresh harvest rice to milled rice ranging from 52$60 \%$ (depends on the variety). It needs to consider processing cost from fresh harvest rice to unhulled rice at IDR $150 / \mathrm{kg}$ unhulled rice. It does not cover freight from the rice fields to the house and from the house to the milling and packing. The data provided by Mr. Agus Susanto stated that if the price level of fresh harvest rice is IDR $4,000 / \mathrm{kg}$, taking into account depreciation, transportation cost, packing, the price of milled rice must be greater than IDR $8,000 / \mathrm{kg}$.

The existence of such rice mills is currently not effective because the harvest is not milled in the village and the milled rice belongs to the farmer for household consumption only. There are also rice mills that produce rice, but the grain supply is from rice fields owned by the millers. The mills in this region that are working have entered into contracts with large traders in Palembang.

\subsection{Efforts to Improve Rice Milling Results}

To overcome the above problems, according to the rice mill owner, the milled rice selling price should be more profitable for farmers compared to selling the fresh harvest rice. In Sumber Hidup Village, the milling owner said that it needs to limit the fresh harvest rice 
sales to large businessmen. Besides that, the milling owner also chooses to turn on or develop the paddy dryer (Table 4). Even in Muliasari Village, the owner believes that there is a need for partners to collect rice. With this partner, the mill must provide unhulled rice, so that the milling operation will continue.

Table 4. Mill owner's opinion to increase the operation of rice milling in the village

\begin{tabular}{|l|c|c|}
\hline Description & Muliasari Village & $\begin{array}{c}\text { Sumber Hidup } \\
\text { Village }\end{array}$ \\
\hline $\begin{array}{l}\text { Restricted fresh harvest rice sold to large entrepreneurs (\% } \\
\text { mill owner) }\end{array}$ & - & 80 \\
\hline Turn paddy dryers on in the village (\% mill owner) & - & 60 \\
\hline Use of by-products (husk/bran) (\% mill owner) & - & 40 \\
\hline $\begin{array}{l}\text { Selling milled rice must be more profitable than fresh } \\
\text { harvest rice } \\
\text { (\% mill owner) }\end{array}$ & 100 & 80 \\
\hline Have own buyer (partner) (\% mill owner) & 40 & - \\
\hline
\end{tabular}

Note: respondent can choose more than one answer

Besides the rice milling owner, farmers also have an opinion to overcome the problem of decreasing rice milling activity (Table 5). Selling milled rice must be more profitable than selling fresh harvest rice is the dominant answer. It means that the milled rice selling price must be feasible and provide benefits compared to if the farmers only sell fresh harvest rice. The second most common answer is to revive/develop grain dryers.

Table 5. Farmer's Opinions for rice milling in the village to increase the operations

\begin{tabular}{|l|c|c|}
\hline \multicolumn{1}{|c|}{ Description } & Muliasari Village & $\begin{array}{c}\text { Sumber Hidup } \\
\text { Village }\end{array}$ \\
\hline $\begin{array}{l}\text { Restricted fresh harvest rice sold to large entrepreneurs (\% } \\
\text { farmer) }\end{array}$ & 45 & 50 \\
\hline Turn paddy dryers on in the village (\% farmer) & 40 & 45 \\
\hline Use of by-products (husk/bran) (\% farmer) & 15 & 5 \\
\hline $\begin{array}{l}\text { Selling milled rice must be more profitable than fresh harvest } \\
\text { rice (\% farmer) }\end{array}$ & 70 & 65 \\
\hline
\end{tabular}

Note: respondent can choose more than one answer

Low prices have hampered the modernization of rice farming. The utilization of byproducts is still limited. Sometimes it even becomes waste and pollutes the environment, especially in rice production centers during the rainy season. By utilizing these by-products, the added value can be enjoyed by the community in the village. Studies have shown that rice bran, rice bran oil, rice husk, and broken rice have potential for health, animal, and alternative food uses and can be produced sustainably as they are considered as renewables. Moreover, the byproducts of the rice milling process can provide an economic boost for rice producing nations [19]. The study conducted in Vietnam [20] show that rice husk firewood is popular because it is more affordable over traditional firewood. Their rice husk pellet exports have boosted the economy because of material convenience shipping.

Harvest improvement and post-harvest handling are the first steps to encourage the development of the rice agro-industry, one of them is the use of artificial dryers, namely solar bubble dryers [17]. Sustainable and efficient production systems are fundamental to maintain industry competitiveness, decrease the use of natural resources, and reduce the environmental burdens created by its production systems [21]. South Sumatera Assessment Institute for Agricultural Technology has conducted a study to improve post- harvest handling to reduce yield losses and improve the quality. One of them is by modifying the 
artificial dryer with husk fuel from 3 tons of original capacity to 10 tons with a drying time of 8-18 hours. Currently, the use of fuel by the community is varied, such as husks, wood and bran.

Based on existing conditions, the following policy recommendations are given to overcome the problems. The policy suggested even though it has been stated by several parties in various meeting forums or papers, it needs to be re- emphasized about how important the implementation and the suggestions and findings are as follows:

\subsubsection{Guaranteed more favorable selling prices for rice}

Rice drying and milling require additional costs such as transportation cost from the rice fields to the house, drying cost, transportation cost from the house to the factory, milling cost. Especially if coupled with the risks that must be faced by farmers, like rains when drying will make rice broken.

They also think the fresh harvest rice price that they have received is reasonable because the price difference between milled rice and fresh harvest rice is not able to cover costs incurred such as transportation, drying, milling, and packing. The milled rice price may be conditioned by rice entrepreneurs so that they are not interested in processing fresh harvest rice into the milled rice. This can be expected with the higher price of fresh harvest rice that can be paid by rice entrepreneurs from Lampung Province compared to Palembang. So to make farmers interest in selling milled rice instead fresh harvest rice, the main factor to consider is the guarantee of the milled rice selling price which should be more profitable than fresh harvest rice.

\subsubsection{Rice processing diversification}

Rice milling produces by-products such as husks, bran, and groats. Husk can be processed into charcoal and briquette. Bran can be used and processed for animal feed. The groats in the form of rice fragments can be processed into various food ingredients.

The premium rice business is one of the ways that can be done to increase sales value, but the capital investment is needed to complement and improve existing equipment in addition by utilizing the by-products. Currently, an integrated rice processing unit can be made, but it requires large capital. Thus it can be made in per-unit form (not integrated) for example, to make briquette charcoal, drying or unified drying with rice mill. The impact of this diversification is to increase added value and opens employment opportunities.

Without realizing it, the resources that are carried out of the village in the form of husks that can be turned into bio silica, biochar, and liquid smoke, and by-products in the form of rice bran all belong to rice entrepreneurs (buyers). By processing grain into rice, to make rice milling active again, the benefits derived from changing the husk into other forms are enjoyed in the village by the mill owner. To make it happen, the artificial drying process must be carried out. But, the weaknesses that occur in the drying process such as the fuel smell and smoke must be overcome first.

\subsubsection{Reactivating post-sale activities through the use of food barns}

Food barn is used to secure the price of crops in a decent position (profitable for farmers). Therefore the food barn is made to accommodate the harvest so that the sale can be postponed, and will be released at a profitable price position for farmers. Now, the existence of food barns is relatively not functioning in the tidal swamp region. 
This post-sale activity is also carried out by utilizing rice mills and farmers' warehouses. It needs support from artificial dryers. Drying facilities are used to accelerate the drying process from fresh harvest rice to unhulled rice. It can reduce yield losses. It also needs support by upgrading the old rice mill.

\section{Conclusion and Suggestion}

\subsection{Conclusion}

- Increased rice CI does not cause increase in rice milling work capacity. It is because farmers sell their fresh harvest rice immediately, as more profitable result for farmers selling fresh harvest rice compared to milled rice. As well as the lack of time and labor that is not enough to dry fresh harvest rice because they have to plant paddy again to increase CI. This happens in both easy and relatively difficult locations to reach.

- Reactivating rice milling has an impact on the use of leftovers such as husks and bran for the needs of farmers so that the added value can be used in the village.

\subsection{Suggestion}

This kind of survey should also be carried out in other agro ecosystems such as irrigation and rainfed to find out whether the increase in CI affects the increase in rice milling capacity, and how is the current volume of rice mill compared to the increase in CI has not yet occurred.

\section{References}

1. Asaduzzaman M., M. Ahiduzzaman and M. Mahhzab. Bangladesh Institute of Development Studies (BIDS) Policy Briefs No. 1402, April 2014.

2. Hutapea Y. and B. Raharjo. Proceedings of AESAP 2016 - The 1st International Conference on the Role of Agricultural Engineering for Sustainable Agriculture Production: 123- 127 (2017)

3. Syahri, B. Raharjo, S. Harnanik, R.U. Somantri and Y. Hutapea. Proceedings of AESAP 2016 - The $1^{\text {st }}$ International Conference on the Role of Agricultural Engineering for Sustainable Agriculture Production: 33-37 (2017)

4. Limbong, I., M.B. Darus dan Emalisa. Journal of Agriculture and Agribusiness Socioeconomics. Vol 4. No. 12 (2015)

5. Sartika dan Ramdhani. Jurnal Ilmiah Rekayasa Pertanian dan Biosistem, Vol. 6, No. 1: 53-59 (2018)

6. Dinata, R.A. Analisis Kelayakan Finansial Usaha Penggilingan Padi Keliling Di Kabupaten Pringsewu. Skripsi Pada Fakultas Pertanian Universitas Lampung, Bandar Lampung. 86 hal (2017)

7. Sabir, N. Analisis Kelayakan Usaha Penggilingan Padi Keliling (Studi Kasus Usaha Penggilingan Padi Keliling Di Desa Tumale Kecamatan Ponrang Kabupaten Luwu). Skripsi pada Program Studi Agribisnis Fakultas Pertanian Universitas Hasanuddin, Makassar. 99 hal (2018)

8. Jerry, A.T. Profitability of Rice ProcessingAmong Youths in Benue State, Nigeria. A Paper Presented in Vande-Ikya Youths Rice Cooperative Society. 14 ${ }^{\text {th }}$ April, 2016. 
9. Tondo, D.T. International Journal of Environment, Agriculture and Biotechnology (IJEAB).Vol-2, Issue-6, : 2776-2782 ( 2017)

10. Ndirangu, S.N. and W. A. Oyange. Journal of Agriculture and Veterinary Science (IOSR-JAVS. Volume 12, Issue 1 Ser. III :38-47 (2019)

11. Swastika, D.K.S. Indonesian Journal of Agricultural Science 13(1): 35-42 (2012).

12. Muhammad M., Liyantono, Y. Setiawan, and A. Fatikhunnada. Procedia Environmental Sciences 33: $44-53$ (2016)

13. Thin, K.C.C and P.P. Thant. International Journal of Engineerring and Aplied Sciences (IJEAS), Vol. 5, Issue-11: 1-6 (2018).

14. Sahari, Y., A. Wahid, R., Mhd Adnan, A. S., Sairi, M., Hosni, H., Engku Abdullah, E. H., Alwi, S., M. A. Tawakkal, M. H., Zainol Abidin, M. Z.and Aris, Z. International Food Research Journal 25 (6): 2572-2578 (2018).

15. Nguyen V.H., H.T. Duong and M. Gummert. International Agricultural Engineering Journal, 25 (1): 64-73 (2016)

16. Zangsayane, Y., K. Vongxayya, S. Phongchanmisai, J. Mitchell and S. Fukai. Plant Production Science Vol 22, No.1: 98-106. (2019)

17. Hung, N. V., T.V. Tuan, P. Meas, C.J.M. Tado, M. A. Kyaw and M. Gummert. Plant Production Science Vol. 22, No.1: 107-118 (2019).

18. Nurliza, E. Doloroza, A. H.A. Yusra. AGRARIS: Journal of Agribusiness and Rural Development Research, Vol. 3 No. 2: 84-92 (2017).

19. Bodie A.R., A.C. Micciche. G.G. Atungulu, M.J. Rothrock Jr and S.C. Ricke. Frontiers in Sustainable Food Systems. Vol. 3 Article 47:1-13(2019)

20. Truong, A. H., Tran, H. A., and Ha-Duong, M. Handbook of Biomass Investment in Vietnam Energy Association. Hanoi: Vietnam Energy Association, 1-17(2016)

21. Pagotto M. and A. Halog. Journal of Industrial Ecology. www.wileyonlinelibrary.com/journal/jie: 1-11(2015) 